\title{
Retention of Girls in School through the Implementation of the 2011 Education Act in Lusaka and Central Provinces of Zambia.
}

\author{
Mukuka Mulenga-Hagane*, Peggy Mwanza \\ The University of Zambia, School of Education, Department of Educational Administration and Policy Studies, \\ Po Box 32379, Lusaka, Zambia
}

*Corresponding Author: Mukuka Mulenga-Hagane, the University of Zambia, School of Education, Department of Educational Administration and Policy Studies, Po Box 32379, Lusaka, Zambia

\begin{abstract}
This article seeks to show how the 2011 Education Act is being implemented in primary schools in Zambia as a tool to keep girls in school. It specially analyses sections 17 and 18 of the Education Act that relates o absenteeism and prohibition of early marriages. These sections further recommend jail sentences to parents or guardians or whoever impedes on the rights of the girls to be in school. The data was collected through semi structured interviews with head teachers in seventeen schools with evidence of absenteeism and pregnancies. The study was informed by the deterrence and attribution theories. Research findings show that while school administrators are willing to implement the contents of the Education Act of 2011 in Zambia relating to absenteeism and early marriages, the local environment is not ready for such drastic measures. In some areas there are no justice institutions close to them to help them invoke the law. Furthermore, there has been a lack of awareness on what the Act entails. For this reason, it was found that none of the schools studied are implementing the 2011 Education Act. School administrators such as head teachers were of the view that there were other humane ways of dealing with absenteeism that did not include the enforcement of the law. In addition, head teachers explained that cases of early marriages are difficult to follow up because communities themselves shield offenders. The legal and local environment cemented their lack of belief that the Act can be implemented so as to deter these vices. Upon reflecting on the responses from the school administrators, it is recommended that, government create awareness on the importance and implementation of the 2011 Education Act, they should also improve efficiency in the justice system. Lastly, government should create formal justice systems closer to the people and improve infrastructure in rural and peri urban areas.
\end{abstract}

\section{INTRODUCTION}

Zambian schools have had higher levels of absenteeism and low retention levels for girls since inception (Kelly, 1996, Mwanakatwe 2012, Kelly, 1996, Snelson, 1974). To address this, subsequent governments through the Ministry of General Education have on numerous times designed frameworks to support the access and retention of girls in school. Prominent among these are the Rerentry Policy, free Primary Education Policy, differential cut of points system between boys and girls. To some extent this has improved the retention of girls in school, however, challenges still lie ahead. This is because despite employing these strategies, absenteeism and retention rates have continued as only $27 \%$ girls complete secondary education (Ministry of Education 2015). For this reason, the Government has devised other methods of ensuring that parents and guardians retain girls in school. This was through repealing the 1966 Education Act and replacing it with the 2011 Education Act. This has been hailed as a milestone in the promotion of equity and equality of access for both genders. This Act among others recommends jail sentences and fines for parents and guardians that do not ensure daily attendance of their children in school and those that marry off learners who are children. This is in line with article 17 and 18 of the Education Act. This study was undertaken between July and August 2017 in order to investigate how Sections 17 and 18 of the 2011 Education Act are being implemented in primary schools in Zambia.

\subsection{Aim}

The aim of the study was to establish how the 2011 Education Act was being implemented to promote retention of girls in school. 
Retention of Girls in School through the Implementation of the 2011 Education Act in Lusaka and Central Provinces of Zambia.

\subsection{Objectives}

In order to address the aim, the following objectives were used:

- To assess awareness of school managers in primary schools of the 2011 Education Act.

- To investigate the motives of implementing Sections 17 and 18 of the 2011 Education Act in schools.

\subsection{Literature Review}

Discussions about girls' participation in school in Africa have become common topics since the conference in Kenya in 1985. The aim of this conference was to evaluate the progress that was made during the United Nations decade for women. They also wanted to devise measures that ensured empowerment of women in regard to health and education. Many studies have been done in Zambia to highlight the plight of the girl child. This includes studies by the Ministry of Education in (MoESVTEE, 2015; Stromquist, 1989; Kelly, 1994; Mitchell, Blaeser, Chilangwa and MaimbolwaSinyangwe, 1999; Mwanza, 2015).

Mitchel et al (1999) carried out an extensive research on access, retention, completion and achievement of girls in schools in Zambia. Similarly, Kelly (1994) conducted studies on factors impeding the retention of girls in schools in Zambia. These include cultural norms and division of labour. Furthermore, the Ministry of General Education through the Programme for the Advancement of Girls Education has been involved in research and has highlighted practices and tendencies that hinder retention such as lack of parental support and school infrastructure as well as other discriminatory tendencies.

However, there have been little or no studies on the impact of education law on retention in Zambia. None of the aforementioned studies looked at the impact of the 2011 Education Act on retention. In addition, none of these researches covered the use of punishment in form of jail terms as covered in section 17 and 18 of the 2011 Education Act as means to compel parents and guardians to retain girls in school.

Whilst studies, in education law have advanced in other countries such as South Africa, and Western countries such as Australia and United States of America, in practice, countries like Zambia are still heavily reliant on policies, circular and education philosophies in daily administration that may be contrary to the rights based approach to education. The 2011 Education Act recommends using the school as a starting point of implementing section 17 and 18 of the 2011Education Act. For this reason, head teachers have a role to play on various issues that will promote the wellbeing of learners and communities in which they operate. This includes evoking the laws by implementing the 2011 Education Act.

In the past, schools have been accused of reinforcing inequalities (Mc Cauley-Brown, 2010, Mort and Ross, 1957). Scholars cite negative behaviour of teachers and administrators. Many of these have concepts of stereotypes which they 'trout out' on every possible occasion (Mort and Ross:1957). The role of administrators is therefore important in this regard. Luangala (2008) describes school managers as key personnel in the education chain. Many issues that are raised in schools have to be addressed by administrators. Mort and Ross (1957:20) further indicate that there is a classic pattern that has to be followed in resolving issues of administrative nature. They mention these steps as' problems identified, brought to the administrator from decision, decision rendered and decision implemented' (Mort and Ross, 1957:20). An administrator who has little interest or less knowledge in an issue presented to him would often be reluctant to act even in the face of the law or policy that states so. There are also administrators that are indifferent to situations in their settings. Some of the studies that have been undertaken have tried to show the link between girls' retention in school to administrative inertia or reactivity to implement retention laws (Faweza, 2010, Mort and Ross, 1957).

Furthermore, when rights to education are infringed upon, litigation seems to be the only option. Retention here through litigation means using the available court systems, in this case the magistrate courts as the starting point to prosecute cases of perpetual absenteeism and early marriages as is recommended for in the 2011 Education Act. It is vital that the justice principle is used in the administration of schools. The justice principle protects the person from harm and courts in this cases 
are supposed to deal with daily injustices that may occur in school settings. The question is whether educational administrators are willing and ready to put the injustice that occurs to a few people against the pressure of maintaining general orderliness of the school system.

\section{MeThOdOLOGY}

\subsection{Design and Sampling}

The study was conducted in Lusaka and Central provinces of Zambia. The study was qualitative and employed the multiple Case Study Design. Bryman (2012) defines a case study as that which involves studying a single case intensively, he however, extends it to include a study of two or more settings that are included for comparative purposes. It is the latter part of definition that situates this study on how the 2011 Education Act is used to retain girls in school into case study realm. Each of the cases were studied in depth as well looking across for similarities and differences. This study used unstructured interviews, participant observation and document analysis. Cases were selected based on the following criteria, they must have had two or more learners absent daily and they must have recorded cases of pregnancies in the period between 2011 and 2017. Purposive sampling was used to select the schools as in afore mentioned criteria. seventeen primary schools were sampled. The sample consisted of 17 head teachers and 17 teachers and an officer from the Ministry of General Education. In addition, through snowball sample, the study added people that had experience and characteristics that were relevant to the study.

\subsection{Methodology}

Data was collected by semi structured interviews with the head teachers in the studied settings. The researcher carried out all the interviews due to the nature of the study that required that the researcher paid particular attention to the responses.

Semi structured interviews helped in the collection of in depth information. This was because they comprised both open ended and closed questions that helped to in this study gauge to what extent the participants were knowledgeable about the studied phenomenon. It was also possible to digress to other issues that informed the study thereby enriching data. Kasonde- Ngandu (2013) and Kombo and Tromp (2011) gives a disadvantage of this form of instrument in that it can be time consuming and that analysis of data may be problematic. Furthermore, Ghosh (2015) adds that there are setbacks to the use of interviews such as the interview can be a source of subjective information whose truth may be difficult to verify. In addition to semi structured interview questions, this study used vignette questions. Vignette question involved giving a brief literally description of the theme. Bryman (2012) defines vignette questions as those questions that are meant to 'tease out respondents' norms' concerning the nature of the case at hand. Vignette questions are often used when topics are sensitive and often give participants freedom to respond based on situations they are given and not necessary based on their own experiences. Secondary data was collected through reviewing documents related to the study.

\subsection{Data Analysis}

Data analysis was done through thematic analysis. Bryman (2012) as well as Kombo and Tromp (2011) indicate that the idea in thematic analysis is to build a group or an index of themes and subthemes and compare and see if they answer research questions.

\subsection{Data Validation and Trustworthiness}

Methodological triangulation has been advised as it validates data (Bryman, 2012, Kombo and tromp 2010, Guba and Lincoln 1994).In this study, the researcher actively dealt with threats to validity by rigorously checking data and the sources. She ensured that all necessary information that helped achieve objectives were sought and used. She also ensured that she did not discard data that was useful to the study, neither did she ignore important sources of information. She also ensured that the theories that she used were the only way to explain the data that she collected. Therefore, the researcher did not have what Maxwell (2013:123) would call 'alternative explanations' to data that was collected. The explanations often reduce credibility of information. In addition, she not only relied on semi structured interviews but also used observations to counter check if data collected tallied with what was said. She followed up participants and asked follow up questions and asked for 
clarification were necessary. She constantly moved from interviews, specific observations and document evidence to validate the data. The main thrust in the research process was on the question of whether through the questions that were posed; the responses were categorized and coded in line with tenets of qualitative study. In order to ensure validity of data, the researcher cross checked sources, made follow up calls to ascertain that the recorded responses were correct. Results were verified with participants, just after interviews.

\section{RESEARCH FINDINGS AND DISCUSSION}

\subsection{Gap in Head teacher awareness of the 2011 Education Act}

Data collected in the three sites revealed that there is a knowledge gap among head teachers on the existence of the 2011 Education Act. It was found that only six of the seventeen head teachers interviewed were aware of the existence of the 2011 Education Act. From the seventeen head teachers interviewed, three head teachers in Lusaka substantiated that they had knowledge about the 2011 Education Act, one head teacher in Chongwe and two head teachers in Kabwe respectively. Summarily, the study recorded different responses which ranged from vague comprehension to complete lack of knowledge on the existence of the 2011 Education Act. One of the responses is cited below from the school head teacher at School A in Lusaka:

'I have been head teacher for 13 years, what is this Education Act, I have never heard of it. I have never had issues that required me to read this Act. I have the documents that I need. What we have is what we often use in daily administration'. All but one respondent showed that they rose to the position of head teacher after many years of teaching experience, despite this, the Education Act was not listed among the documents used in administration as a participant from School G in Lusaka explained.

I have been in this position for a long time now since 1995. Before this position, I was a class room teacher. I have been to many meetings within the Ministry of Education, and I have never come across this document, not even among cross cutting issues.' A participant from School A in Lusaka further stated that what she knew was learnt through administration experience. 'What I know I have learnt through experience and trying, there has not been orientation at all so I don't know about this document'. There were a few teachers that had information on the existence of the 2011 Education Act, one of them was a Head teacher from School Z in Chongwe,

'I have been a head teacher for 4 years now. Yes I am familiar with this document. As you can see, It is among the list of useful resources we need to have in the school from the Ministry of Education'. There were also voices that depicted knowledge without necessarily seeing it as being useful in work situations. This was registered by a Head teacher from School $\mathrm{J}$ in Kabwe, 'I am familiar with the document, I have it somewhere in this office but I have not read through it. I also read parts of it as part of my course work at university.' Some respondents in all the three sites denoted that they did not realize that there was an Act governing the education system as is summed up in the following response from a head teacher from School B in Lusaka 'I did not know about the 2011 Education Act, we do not even have it here, how different is it from the policies and circulars that we have been following? Another head teacher from School P in Chongwe retorted that he was not familiar with the 2011 Education Act and attributed this to being a newly promoted head teacher in the education system. 'I have been a head teacher for the past two years; I do not know anything about the Education Act. Maybe it is because I am new in this position'.

Although the knowledge gap pertaining the 2011 Education Act was low, all the head teachers in this study were familiar with other education documents such as the current national policy on education, Educating our Future as well as the re-entry policy that advocates for girls readmission to school after they get pregnant and deliver. This they indicated was as a result of government and Non Governmental Organisation efforts. As the head teacher at school K in Kabwe explained 'I have been head teacher for the past ten years, this is news to me. The documents I know are the re-entry, especially for girls, I have had workshops on the same over the years'

The head teachers who expressed ignorance about the 2011 Education Act attributed this to lack of information from the Ministry of General Education and stated that perhaps the Act was not something they could use on a daily basis as one head teacher from School A in Lusaka 
acknowledged 'I have been head teacher for four years, I do not know about the Education Act but I am familiar with other documents such as re-entry policy that I have used in my work. I have not had any information from the ministry.'

The gap in knowledge relating to the 2011 Education Act correlates with the Ministry of General Education report of 1992 and the Ministry of General Education National Policy of 1996. These aforementioned documents highlighted the lack of general managerial competences among head teachers to carry out their work effectively. It was acknowledged in the aforementioned documents that many head teachers lacked training. This contributed to them carrying out decisions haphazardly. The reports also blamed head teacher ineffectiveness on the system of tenure. Furthermore many head teachers rose through the ranks and were promoted by the system which the report indicated gave undue protection to incompetent head teachers. Ministry of Education (1996) policy on education states that there were knowledge gaps among head teachers in areas such as industrial law, visionary leadership among others. The end result was seen in lack of implementation of government policies. In line with this explanation, Lipsy (2010) emphasised the importance of street level bureaucrats such as head teachers, in the implementation of policy. Lipsy highlights the role of individual action as an important factor that can drive change in organisations and lead to desirable outcomes. But this individual effort is only possible when street level bureaucrats are involved and awareness created.

The researcher argues that since head teachers provide vital links which may lead to prosecution of offenders, the Ministry of General Education must devise a deliberate plan to invest in their training. So far, few participants were cognisant of the impact of their lack of knowledge on Education Act. Reason being, as the attribution theory states, it is always easier to blame others for failures and not oneself. The failure to implement the 2011 Education Act according to head teachers was the environment and the lack of information from the Ministry of General Education. In discussing attribution theory, Weiner (1995) gives conditions that may lead to participants attributing a cause to the environment or to individuals. He states that the more one knows about the environmental conditions surrounding the behaviour, in this respect learner absenteeism and early marriages, the less likely that this behaviour is internally drawn. The other evidence would be that the behaviour persists even in the presence of inhibiting force, which in this context would be the law. Whilst absenteeism and early marriages can be assumed to be externally drawn, conditions tabulated by Weiner have not been used to classify them in this grouping. The inhibiting force has not been used in this instance for the reason, blame must be apportioned accordingly.

\subsection{Sacrificing a Few Learners to Help the Majority}

Almost all respondents in the study indicated that the absentee numbers and the figures of girls getting pregnant where negligible in comparison to the other learners who were eager to be in school. Henceforth explained a head teacher from School $\mathrm{J}$ in Kabwe in this school none of the girls have fallen pregnant but of course I have those that have been absent more often than others but they keep coming back so that is good. We have many that are in school and want to stay in so this is a good sign.' In addition, some head teachers interviewed indicated that there was a lack of encouragement to pursue issues outside teaching and learning. 'the school has not money allocated to this' bemoaned the head teacher at School K in Kabwe. While all respondents sympathized with the increase in the number of learners falling pregnant, and early marriages, individual cases in schools did not however inspire head teachers to follow and allocate time in pursuit of these cases. Their concern was on how they were often taken to task by educational authorities whose main focus was on academic performance albeit under difficulty circumstances. The respondents further said that what they focused on was the welfare on the whole school. One head teacher from School A in Lusaka observed thus 'at times you have to see what is really important. Chasing one child who is perpetually absent or ensuring that those that want to learn and are in school are taken care of. I have to send reports when the children do not perform well, that is on my list of problems.'

\subsection{Discourse of Punishment Stated in the 2011 Education Act Understated by the Head Teachers}

On the other hand, the dominant dimension of responses from all the participants in the study who are head teachers involved anti punishment discourse. Discourses that emerged hinged on dialogue, discussion, rehabilitation, counselling and ethics. This they said should be the basis and what all that 
should prevail in the education system. Similarly finding was indicated by Consedine (1995) in his study among the Maori in New Zealand. Consedine found that punishment through prison terms did not bring out intended positive results. This was especially among the poor, who in many instances had so much going against them. This correlated with sentiments from one respondent from School $\mathbf{J}$ in Kabwe 'jail was never a good response to issues that the school had because communities were disadvantaged and this would only worsen the already bad situation'. The focus, he suggested, 'has to be, as it has always been, on dialogue with parents to resolve instances of absenteeism and early marriage cases and not the threat of prison'. This fear was reflected by respondents in the study who alleged that the harsh laws would lead to more deterioration in the education sector. The another head teacher from School C in Lusaka further stated that 'If we have to follow up all the cases we have of especially absenteeism without justifiable cause, half of the country will be in prison or will be asked to pay fines.'

\subsection{Fear of Community Reprisals}

This study established that while the head teachers agreed on the importance of education laws as in the 2011 Education Act that involve invoking the law and the court system in order to ensure retention of girls in primary school, they were reluctant to implement as one head teacher from School C in Lusaka put it 'I will not do something that they say will create tension in communities'. The study found that head teachers were afraid of the reaction of the local people to the law more than the law itself. This is a social cost of change that head teachers were not willing to pay for. 'Let us be honest, we have to live in these communities', indicated the aforesaid head teacher from Lusaka, ' who will save us from the wrath of the locals, this has never been done. Already we are pleading to have relationship with them (the community), I think threats, by using the law will make things worse and our work more difficult.' The study further found out that head teachers believed that the Education Act while aiming at addressing cardinal issues in education was not grounded in reality as it did not take in to account the culture, geographical and social systems 'The people who came up with this law did not think of us.' Said a head teacher from School $\mathrm{N}$ in Chongwe. 'it is already tough to live here and encourage these learners to come to school and for their parents to let them come to school.' Some head teachers took great exception at the type of law enacted that did not align to the realities of the people. As a head teacher at School L in Kabwe advised 'this law must be revisited, there are other things that must be put in place before I can comfortable to take action against those that break the law.' While head teachers in this study agreed that parents need to be proactive in the education of their children, they believed there were compassionate ways of dealing with the problem of learner absenteeism that does not involve law enforcement. According to the head teacher at School $\mathrm{Z}$ in Chongwe, 'imprisoning parents will not increase adherence to the law, neither will it improve attendance but will create resentment between communities and educators.' In addition, 'prison sentences will only increase the number of incarcerated people in prison as well as child headed households'. This he said 'will still impact attendance levels in schools.' A head teacher in at School $M$ in Kabwe revealed that it was often difficult to follow up cases of early marriages in that communities often shielded perpetrators. In some cases when teachers made follow ups they are threatened by the community, in one incident it was reported that communities threatened teachers with expulsion from their communities. The study was informed that in some cases, parents moved to other settings just to ensure that their will prevailed over their children. 'Schools can only do so much, we cannot follow them when they move to other towns' retorted a head teacher at school $\mathrm{Z}$ in Chongwe. The study found that cases were parents decide to move the child away from the place to marry them off still going on. A head teacher at School M in Kabwe explained that 'there have been instances of early marriages, or children taken away or parents insisting that children themselves often decide to get married.'

\subsection{Community Resistance as a Hindrance to Investigations}

The study established that there had been waning support from the community on issues of absenteeism and retention of girls in school. One respondent at School C talked about how she managed to track down one girl that was alleged to have been married off. She indicated how she was prevented from intervening by the parties involved. 'I was informed that the girl chose to get married herself after getting pregnant, they said under the circumstances they had no choice but to side with the girl, to support her'. She further added that 'societal beliefs are that a child must be raised by both 
parents; in this case the pregnant girl was to set up house with the boy as marriage negotiations had already taken place. Parents to the pregnant stated that girl had on many occasions run away from home such that it was difficult to track her down without first grounding her by marrying her off'. The same was observed by a head teacher at School $\mathrm{N}$ in Kabwe. She divulged an incident were parents threatened teachers who were following up a suspected case of early marriage incident. 'We followed up a case in the compounds where a learner had married themselves but with parental consent. We could not do anything because the parents and some members of the community sent us back and threatened us to leave the learners alone. They said this is our school and if we want we can chase you from this area.' The fearless action by some members the community are as a result of them weighing consequences of their actions and knowing that they would not be punished. Holsti (1995) explains this in strategic deterrence. The main ideas of strategic deterrence are based on decisions by people to commit crimes. The offender calculates or evaluates the cost and gains of committing crimes, evaluation of the situation is done and careful assessment of relative capabilities of the threat being carried out when he is caught is evaluated. In this study, the threat is the use of 15 year prison sentences and one year sentences plus fines against would be offenders. According to Holsti, the credibility of strategic deterrence lies in the capacity to carry out the stipulated threat. Which was lacking in this cases, in addition, it lies in the perception of the parties involved, for example how they view the threat and if they think that the authorities would carry out the threat. Additional information on strategic deterrence is linked to what extent the parties are informed of the law and the perceived threat if the law is contravened. What the foregoing discussion implies is that, participants in this study would not threaten offenders with prosecution because they had no capacity to follow through with the threat. They instead chose dialogue with the community like they have always done and hoped for better results. This is another face of strategic deterrence that discusses the need to work on the values of the people involved. This it was hoped would reduce the escalation of cases and would reduce the idea of using threats.

\section{CONClusion}

The study made significant observations that can help in the implementation of the 2011 Education Act. The study found that school administrators' habits are yet to be configured in order to enhance promote government retention ideals as found in the 2011 Education Act. In addition, Government needs to put in systems that will constantly promote awareness of new laws and statues. Furthermore, whereas government has introduced the law, the context in which this law should be implemented has not been levelled to allow for this to take place. Therefore, the geographical, cultural and social setting is not ideal to enhance implementation of the 2011 Education Act. The core problems that are being criminalised in the 2011 Education Act learner absenteeism and early marriages, can be addressed by putting in systems that can help in addressing these core problems. People will not fear the law if systems aimed at correcting the situation are non - existent. Instead government must endeavour to address the core of the problem, which are the social structures and processes. They too must invest in systems and institutions that would tackle this.

\section{RECOMMENDATIONS}

Government needs to put in systems that will constantly promote awareness of new laws and statues in schools.

The context in which this law should be implemented should be levelled to allow for this to take place; this may include introducing transportation systems for children in rural areas if it is not feasible to construct schools near them.

Improve efficiency in courts in order to restore faith in the justice system.

\section{REFERENCES}

[1] Bryman, A. (2012) Social Research Methods. New York: Oxford University Press

[2] Consedine, J. (1995). Restorative Justice: Healing the Effects of Crime. Lyttelton: Ploughshares Publications.

[3] Daka, B. and Sinkala P. (2007) Situational Analysis On Education In Zambia; A Case Of Central Province. Lusaka: Unza Press.

[4] Gallagher, W, S. (1999) The Plight Of Teenage Mothers In Europe: London: Oxford Printing PLC. 
Retention of Girls in School through the Implementation of the 2011 Education Act in Lusaka and Central Provinces of Zambia.

[5] Ghosh, B.N (2015) Scientifuc and Social Research Method.New Delhi:Sterling.

[6] Government of the Republic of Zambia (2011) The Education Act. Lusaka: GRZGuba, E and Lincoln, Y (2005) Fourth Generation Evaluation. NewbyPark: Sage

[7] Hatchard, J. (1985) Crime and Penal Policy in Zambia in the Journal of Modern African Studies, Vol,23, No 3. Pp 483-505.

[8] Holsti, K,J (1995) International Politics: A framework for Analysis. New Jersey, Prentice Hall International Editions.

[9] Kasonde-Ng'andu S. and Simwiinji N. (2009). Review Of The Re-Entry Policy In Zambia. MoE/UNICEF.

[10] Kelly M J (1994) Below the Poverty Line in Education: A Situation Analysis of Girls' Education in Zambia. Lusaka: UNICEF.

[11] Kvale, S and Brinkmann, S (2009) Interviews: Learning the Craft of Qualitative Research Interviewing. London: Sage

[12] Lipsy(2010)Dilemmas of the individuaø in public service.Newyork:Russel Sage Foundation.

[13] Luangala P. (2008) Disparaties in Education. Lusaka: UNZA Press

[14] Lungwangwa G, Kelly M J, Sililo E (1999) Basic Education for Some: Factors Affecting Primary School Attendance in Zambia. Lusaka: Study Fund on Social Recovery Project.

[15] Mabula - Kankasa T. and Chondoka, Y, A. (1996). In The Best Interest Of Girl Child: Effects Of Cultural And Legal Environment On Education For Zambian Girls. Lusaka: UNICEF

[16] Mccauley-Brown C. (2005). Pregnant And Parenting Youth. Do We Know How They Fare In School? Public School Notebook, Fall Edition. Retrieved, 13th February 2006, from http://www.Thenotebook.Or/ Editions/2005 /Fall/-8k.

[17] Ministry of Education (2010) Ministry of Education Statistical Bulletin. MOE: Lusaka

[18] Mwanakatwe (2012) Growth of Education In Zambia Since Independence. Lusaka. OUP.

[19] Mwanza (2013) The Role of Non-Governmental Organisations in Basic Education Policy Reform in Lusaka Province of Zambia. The University of Edinburgh. PhD

[20] Mwanza, P(2015) 'The State of Girl-Child Education in Zambia: The case of Chongwe District' in Journal of international Cooperation in Education, Vol. 17, No 2

[21] Northern Rhodesia 1925: Native Circular No 2. File(2/1/1) Lusaka: National Archives

[22] PLAN (2012) Protecting Children from Harmful Practices in Plural Legal Systems. New York: PLAN.

[23] Stapleton A (2007) 'Legal traditions and Values in Inherited from Britain Colonial Past' in Access to justice and beyond. Penal Reform International

[24] Syabwanta, C, K. (2002) Changing Perceptions Towards Girls Education. Lusaka. UNDP (2010) Girl Education In Africa. New York: New York Printers.

[25] United Nations (1948) Universal Declaration of Human Rights. New York: United Nations

[26] United Nations Children's Fund (2013) Every Child's Birth Right: Inequities and trends in birth registration. New York: UNICEF.

[27] Weiner, B. (1995). Judgments of responsibility: A foundation for a theory of social conduct. New York: Guilford.

Citation: Mukuka Mulenga-Hagane, Peggy Mwanza. "Retention of Girls in School through the Implementation of the 2011 Education Act in Lusaka and Central Provinces of Zambia.". International Journal of Humanities Social Sciences and Education (IJHSSE), vol 5, no. 7, 2018, pp. 73-80. doi: http://dx.doi.org/10.20431/2349-0381.0507009.

Copyright: () 2018 Authors. This is an open-access article distributed under the terms of the Creative Commons Attribution License, which permits unrestricted use, distribution, and reproduction in any medium, provided the original author and source are credited. 